\title{
Interdisciplinary Convergences with Biology and Ethics via Cell Biologist Ernest Everett Just and Astrobiologist Sir Fred Hoyle
}

\author{
Theodore Walker Jr.
}

Biology and ethics (general bioethics) can supplement panpsychism and panentheism. According to cell biologist Ernest Everett Just (1883-1941) ethical behaviors (observable indicators of decision-making, teleology, and psychology) evolved from our very most primitive origins in cells. Hence, for an essential portion of the panpsychist spectrum, from cells to humans, ethical behavior is natural and necessary for evolutionary advances. Also, biologybased mind-body-cell analogy (Hartshorne 1984) can illuminate panentheism. And, consistent with panpsychism, astrobiologist/cosmic biologist Sir Fred Hoyle (1915-2001) extends evolutionary biology and life-favoring teleology beyond planet Earth (another Copernican revolution) via theories of stellar evolution, cometary panspermia, and cosmic evolution guided by (finely tuned by) providential cosmic intelligence, theories consistent with a panentheist natural theology that justifies ethical realism.

* This deliberation is a significant reworking of »Advancing and Challenging Classical Theism with Biology and Bioethics: Astrobiology and Cosmic Biology consistent with Theology, « a 10 August 2017 paper presented at the Templeton Foundation funded international conference on Analytic Theology and the Nature of God: Advancing and Challenging Classical Theism (7-12 August 2017) at Hochschule für Philosophie München [Munich School of Philosophy] at Fürstenried Palace, Exerzitienhaus Schloss Fürstenried, in Munich, DEGermany. Conference speakers included: John Bishop, University of Auckland, New Zealand; Joseph Bracken SJ, Xavier University Cincinnati; Godehard Brüntrup SJ, Munich School of Philosophy; Anna Case-Winters, McCormickTheological Seminary; Philip Clayton, Claremont School of Theology; Benedikt Göcke, Ruhr University Bochum; Johnathan D. Jacobs, St. Louis University; John Leslie, University of Guelph; Gesche Linde, University of Rostock; Klaus Müller, University of Münster; Ken Perszyk, University of Waikato; Andrew Pinsent, Oxford University; Thomas Schärtl-Trendel, University of Regensburg; Johannes Stoffers SJ, Munich School of Philosophy; Giovanni Ventimiglia, University of Lucerne; Theodore Walker Jr., Perkins School of Theology at Southern Methodist University; coordinated by Prof. Dr. Godehard Brüntrup SJ and Dr. Tobias Müller; with Niklas Ernst, Fredrich Sieben, and others. 


\section{Biology and Ethics - From Cells to Humans-E. E. Just}

\subsection{Interdisciplinary Convergences with Biology}

Obviously, deliberating about »panpsychism and panentheism« requires attending to psychology and theology. And it may be that logic and argumentation can demonstrate that panpsychism is correct.

Nevertheless, Benedikt Paul Göcke finds that logically valid arguments showing »that panpsychism is correct « do not address »how it is possible that panpsychism is correct« (2018: 231). Also, logically valid arguments do not address empirical questions about actuality. Attempts at »empirical justification « are discouraged by various factors, including »the idea that panpsychism is useless speculation, « the »epistemic asymmetry between mental and physical properties, « the lack of »direct access « to other minds, and the seemingly »completely alien to us« nature of extreme low level phenomena or »proto-mentality« (Brüntrup and Jaskolla 2017: 4). Furthermore, empirical questions are not addressed because logical arguments from panentheist theology, transcendental metaphysics, and transcendental phenomenology are indeed methods appropriate to demonstrating that panpsychism has positive truth-value.

Nevertheless, Göcke's finding stands. Logically valid arguments do not address how panpsychism is possible. And, for addressing how our psychism came to be actual, transcendental deductions need to be inferentially and synthetically related to actual examples, including examples from our nonhuman relatives.

In metaphysics, exemplification does not prove, demonstrate, or justify. Nevertheless, examples can illustrate and illuminate metaphysical truths (logically necessary truths about existence as such). To be sure, actuality describes its part of possibility; and analysis, synthesis, extrapolation, and speculation can describe various other parts of possibility. And, any actual or any conceivable counter-example would demonstrate that a putative metaphysical claim in not a genuine metaphysical claim, even if said claim described a factual/ contingent truth. Hence, in addition to studying logic, transcendental metaphysics, theology, and transcendental phenomenology, for the sake of illustrating and illuminating panpsychism and panentheism, along with studying physics and psychology, we should study biology. ${ }^{1}$

1 We should study biology, including »general biology« (Just, April 1940) and »Theoretische Biologie« [theoretical biology] (Uexküll 1926; and 1934). Also, interdisciplinary convergences with biology in the research university are treated in Undisciplining Knowledge: 
And perhaps not obviously, studying broad-spectrum evolutionary biology, ranging from humans to cells, brings us to yet another discipline: moral theory/ethics.

\subsection{General Biology and Bioethics}

In cell biology, Ernest Everett Just (1883-1941) was a pioneer. He was first to observe and describe the »wave of negativity« spreading around the surface of an egg cell from the entrance point of the fertilizing spermatozoon (thereby repulsing other sperm) and first to describe »fast and slow blocks to polyspermy« (Byrnes 2010). In addition to authoring more than seventy articles, and co-authoring with Frank R. Lillie the chapter on »Fertilization« in General Cytology: A Textbook of Cellular Structure and Function for Students of Biology and Medicine (1924); Just authored The Biology of the Cell Surface (1939a), and Basic Methods for Experiments on Eggs of Marine Animals (1939b), plus numerous unpublished deliberations on general biology and ethics.

E. E. Just advanced »basic methods« (1939b) rigorously attentive to the specific environment that is normal for living specimens. Prior to Just, marine biologists were habitually making uncritical use of specimens (often killedand-fixed) extracted from their normal-natural environments. Just criticized and corrected findings and concepts derived from such faulty methods. And he encouraged attention to development within normal-natural environments. Today, in ecological development biology (eco-dev biology), integrative systems biology, and embryo morphogenesis, Just's contributions are described as pioneering. ${ }^{2}$

Interdisciplinarity in the Twentieth Century (2015) by Harvey J. Graff. And see »Biology, social science, and history: interdisciplinarity in three directions « (2016) by Chris Renwick.

2 Following Just's pioneering lead, in biology, studying the »cell surface « became vitally important (Dover 1954, Grinnell 1975). And concerning Just's pioneering contributions to environmental and ecological development biology, systems biology, and embryo morphogenesis, see: »Law of Environmental Dependence « (Just and Just 1941: 168, 157-165); »Ernest Everett Just, PhD: Pioneer in Ecological Development (Eco-Dev) Biology« (July 2013) by Katelyn M. Williams, Bryan A. Wilson, Wendi G. O'Connor, and Monte S. Willis in Journal of the South Carolina Academy of Science, 11 (1): article 5; and see »Ernest Everett Just (18831941) - An early ecological developmental biologist « (1 August 2006) by W. Malcolm Byrnes and William R. Eckberg in Developmental Biology, 296 (1): 1-11. In »Ernest Everett Just: Experimental Biologist Par Excellence« (February 2010) W. Malcolm Byrnes describes ecological developmental biology as focusing »on development in its natural environmental context, « and he emphasizes Just's challenge to established views, a challenge that has »much in common with what is known today as integrative systems biology, in which a top-down view is just as important as a [established-reductionist] bottom-up view for understanding the system « (Byrnes February 2010). Just's early advocacy of a non-reductionist/ holistic approach is appreciated in »Just and Unjust: E. E. Just (1883-1941)« (August 2008) 
In accordance with his pioneering basic methods, Just held that biology should distinguish without separating living organisms from their living environment. Just says:

The living thing is part of the natural world, it grows and lives on the stuff of which it is made and whence it came. Then living thing and outside world constitute one interdependent unity, as evolution teaches, as the development of an animal egg reveals. ...

(Just 1939a: 366)

The interdependence between individual and outside world is a postulate which has its sanction not from any abstract philosophical principle, but is true because of the biological basis here set for. The best system of philosophy, then, is that which recognizes living thing and outside world as one interdependent continuum. Instead of building our philosophical theories of life on the behavior of electrons, it is safer to erect them on a biological basis. ...

(Just 1939a: 366-67)

Just's biology-based philosophy of nature produced a general theory of life, a »general biology« that identifies phenomena common to all life (April 1940). According to Just, living individuals are parts of the natural world, and »they form together one inter-acting system « (1939a: 356), »one interdependent continuum, « and »one interdependent unity« (1939a: 366-67). Obviously, Just's general biology is consistent with panpsychism and panentheism.

In Biology of the Cell Surface (1939a), where Just was mainly concerned to offer an account of the living ectoplasm interacting with a living environment, he also offered briefly a biology-based theory of ethics, a general bioethics. Just's general bioethics is distinct from special medical bioethics. Special bioethics treats medical ethics among humans. Just's general bioethics treats the evolution of ethical behavior, starting from cells.

The first book using the term »bioethics « was Bioethics: Bridge to the Future (1971) by Van Rensselaer Potter (born 1911, died 2001). Relative to contemporary medical meanings (medical ethics, nursing ethics, biomedical ethics), Potter's original meaning of the term »bioethics « was literally biology converges with ethics. And given this wider scope (wider than medical ethics), bioethics included relating study of land-and-forest to ethics. So Potter dedicated his book to the memory of land conservationist Aldo Leopold (born 1887, died 1948), »who anticipated the extension of ethics to Bioethics« (Potter 1971: v). The

by James F. Crow in Genetics, 179: 1735-1740. Also, in embryo morphogenesis, Just strongly influenced essential concepts (concepts usually attributed to Holtfreter) according to »Ernest Everett Just, Johannes Holtfreter, and the Origin of Certain Concepts in Embryo Morphogenesis« (2009) by W. Malcolm Byrnes in Molecular Reproduction \& Development, 76: 912-921. 
wide scope of »bioethics « allowed adding »global« to Global Bioethics: Building on the Leopold Legacy (1988) by Van Rensselaer Potter. ${ }^{3}$ Here Potter identified Leopold as »unquestionably the first bioethicist « because Leopold was »first to envision a new ethical basis for human conduct « and »first to develop an ecological ethic (which he called the land ethic) ... (Potter 1988: xiii). Hence, bioethicists should appreciate the »pioneering efforts « (Potter 1988: xiv) advanced in »The Land Ethic « in A Sand County Almanac (1949) by Aldo Leopold.

Another pioneering approach to general bioethics, an approach that was pioneering for ecological development biology, was advanced in Biology of the Cell Surface (1939a [also 1933; 1940]) by Ernest Everett Just. In his brief account of biology converging with ethics, Just supplemented a Darwinian emphasis (upon struggle against the surrounding environment) by adding a Kropotkinian [Peter Kropotkin] emphasis upon »mutual aid« and »cooperation « with the surroundings. Just said:

Life is not only a struggle against the surroundings from which life came; it is also a co-operation with them. The Kropotkin theory of mutual aid and co-operation may be a better explanation of the cause of evolution than the prevailing popular conception of Darwin's idea of the struggle for existence. [And with cells, T.W.] The means of co-operation and adjustment is the ectoplasm [the cell surface, T.W.]....

(Just 1939a: 367)

Just agreed with Kropotkin. Natural selection alone cannot explain evolutionary advances. »Mutual aid« and »co-operation« with the surroundings (ethical behaviors) are essential to explaining evolution.

And in Mutual Aid: A Factor of Evolution (1902) Peter Kropotkin had predicted that future research would reveal »mutual aid« among microbes.

With many large divisions of the animal kingdom mutual aid is the rule. Mutual aid is met with even amidst the lowest animals, and we must be prepared to learn some day, from the students of microscopical pond-life, facts of unconscious mutual support, even from the life of micro-organisms.

(Kropotkin 1902: 14)

3 According to H. Tristram Englehardt Jr. of the Center for Ethics, Medicine, and Public Issues, the term »bioethics « now serves »to identify the disciplined analysis of the moral and conceptual assumptions of medicine, the biomedical sciences, and the allied health professions « (Englehardt's foreword to Potter's 1988 book: p. x). In contrast to such medical definitions of bioethics, Englehardt observes that, as used by Potter in 1971, the term »bioethics « had a more general meaning. Similarly, »bioethics« had a more general meaning in »Bioethics: A Review of the Ethical Relationships of Humans to Animals and Plants« (1927) by Fritz Jahr (Hans-Martin Sass 2007). 
Just's study of microscopic life fulfilled Kropotkin's prediction. Just recognized that in order for multicellular organisms to evolve from single cell organisms, or grow from individual egg cells, »co-operation « and »mutual aid« are necessary; and he observed examples of this bioethical principle at microbial levels.

\subsection{Mind-Body-Cell Analogy}

Biology can serve panpsychism and panentheism by supplying an exceptionally illuminating analogy. ${ }^{4}$ Contrary to Krause's explicit argument against understanding panentheism in any spatial way (Göcke 2018: 178-179), a human mind-body-cell analogy adds a spatial metaphor (inside, outside) for panentheism understood as all-inside-God-ism. Biology shows that we are composed of living cells; and experience reveals that a living person is more than the sum of her/his cellular parts. According to Charles Hartshorne's biology-instructed "person-to-cell analogy« for God, all creatures are like cells in the »cosmic body« of the all-inclusive Creator, »outside« of whom »there is nothing « (1984: 59; also 1975 [c1937]: 197).

This biology-based analogy illuminates the panentheist idea that God is the one all-inclusive living individual »in whom we live and move and have our being " (Clayton and Peacocke 2004), the »one all-inclusive whole of reality « (Ogden 1984: 21; also Hartshorne 1973 [1967]: 7, 12, 16; 1975 [c1937]: 25, 72, 163, 208). ${ }^{5}$ Nevertheless, in agreement with Krause, the spatial inside-outside aspect of mind-body-cell analogy fails to show there can be no »outside« of the all-inclusive whole of reality.

\subsection{Partialist Fallacy}

The idea of one all-inclusive-living-loving-creative whole of reality is a panentheistic conception of »the Creator« (in whom we creatures live and move).

4 Biology-based analogy can also serve ethics. For instance, the egg cell's »wave of negativity« repulsing all but one spermatozoon (described by E. E. Just) can serve as an appropriate analogue for marital fidelity (coffee platform conversation with Andrew Pinsent on 10 August 2017 and lunch conversation with Joseph Bracken on 11 August 2017 at international conference on Analytic Theology and the Nature of God).

5 Concerning Hartshorne's panentheism: In the Preface to the 1975 reprint of his 1937 book Beyond Humanism: Essays in the Philosophy of Nature (1975 [c1937]) Charles Hartshorne offers two important »retractions« from his 1937 terminology. He retracts labeling his »neoclassical« metaphysics and theology with the classical term »pantheism « [pan-theism] in favor of labeling it »my panentheism « [pan-en-theism] (italics added); and he retracts labeling it »naturalism « (which implies contingent existence and contingent actuality, instead of necessary existence and contingent actuality) in favor of labeling it »supernaturalism « (1975 [c1937]: viii-ix). As indicated in this Preface, after 1937, Hartshorne's consistent typological label—for his (and Whitehead's) organic cosmology and theology—became »panentheism.« 
Here theology (all-inclusive Creator) is rightly entangled with biology (included creatures and creations). Obviously, from this panentheistic-Creatoraffirming perspective, failure to conceive of one all-inclusive living whole of reality (conceiving only of parts) is a fallacy in theology and biology.

And perhaps not obviously, conceiving only of parts is also a fallacy in ethics. To be sure, this »partialist fallacy « was explicitly named in two books on moral theory (Gamwell 1984; Gamwell 1996 [c1990]).

In Franklin I. Gamwell's The Divine Good: Modern Moral Theory and the Necessity of God (1996 [c199o]), »partialist fallacy« labels a failure to refer to the all-inclusive whole of reality that includes »the divine good « which is »the comprehensive variable that identifies the good as such « (1996 [c199o]:149n.15, 178). Similarly, the logical necessity of reference to divine goodness in ethics is developed in chapter 4 »God and Righteousness « in Man's Vision of God and the Logic of Theism (1941) by Charles Hartshorne. According to Hartshorne, theology serves theory of value by providing »explicit recognition « of » the whole of which all lesser values are parts « (Hartshorne 1975 [c1937]: 25). Following Hartshorne, Gamwell finds that the »partialist fallacy« (failure to refer to the divine whole) has been characteristic of modern moral theory since Immanuel Kant. And because reference to God (whose necessary existence is demonstrated by valid metaphysical arguments) and the divine good is a necessity for adequate moral theory, modern moral theory is necessarily inadequate.

\subsection{Partialist Fallacy in Cosmology}

In addition to recognizing the partialist fallacy in biologically-psychologically entangled theology, and in moral theory, we should also recognize the partialist fallacy in cosmology. Though the very word »cosmos « implies a cosmic whole, many cosmological theories refer only to parts of reality. Referencing only parts of reality (even all parts of reality [for example, in one form of pantheism God is the sum of all parts of reality]) can yield only inadequate accounts of cosmic reality.

The term »big bang « (a term coined by »steady state « advocate Fred Hoyle) encourages committing the partialist fallacy by suggesting analogy to an exploding bomb or grenade. With a bang, a grenade explodes into many fragments, obliterating the whole grenade. For the sake of correcting our tendency to conceive only of parts, we should notice that unexploded whole grenades are parts of the whole of reality, and that exploded grenade fragments are also parts of the whole of reality. Unlike parts of reality, the whole of reality is eternally all-inclusive. Cosmology should include recognizing that whether exploding/expanding or collapsing, or in some relatively steady state, all parts of reality are parts of the cosmic whole of reality. 
To conceive only of parts (as though there could be parts of no whole of reality) is to commit the partialist fallacy. Where the partialist fallacy is avoided, cosmology converges with theology and moral theory.

\subsection{Ethical Behavior Rooted in Biology}

In moral theory, when going beyond the logically necessary metaphysics of morals, in addition to avoiding the partialist fallacy by referring to the necessary whole of reality (the divine good), an adequate moral theory must also refer to unnecessary/contingent factual examples. And according to Just, moral theory should have roots in biology. »Here«—among non-reductionist theories of life instructed by observations from biology, including cell biology—»we may seek the roots of man's ethical behavior « (Just 1939a: 367 ). In the final footnote in Biology of the Cell Surface, Just said he would »deal with this point at greater length « in a »forthcoming « work (1939a: 367 ).

Tragically, before he could persuade a publisher to print said forthcoming work on the biological roots of human ethical behavior, Just died in 1941. Thankfully, manuscript pages are preserved at the Howard University Moorland-Spingarn Research Center.

\subsection{Biological Origins of Ethical Behavior}

»The Origin of Man's Ethical Behavior (1941, unpublished manuscript ${ }^{6}$ ) was co-authored by Ernest Everett Just and his research associate Hedwig A. Schnetzler Just. In the opening chapter »The Problem Stated, « after rejecting the idea that moral theory should be restricted to religion and philosophy, Just and Just say: »... we intend to treat ethics as a problem in biology ... It is within the field of biology, then, that we locate human ethics, or better to say, man's ethical behavior« (Just and Just 1941: 2-3 [also 4, 91, 146]).

6 »The Origin of Man's Ethical Behavior« (October 1941, unpublished manuscript) was previously called »Ethics and the Struggle for Existence« in a 15 April 1941 letter from Just to J. W. Buchanan (Kenneth R. Manning 1984: 327, 385 note 12); and referenced as »some 400 typed pages « (including annotated bibliography) in a 15 October 1940 letter from Just to W. C. Allee; and referenced as »a forthcoming essay« in Just's 1939 book-The Biology of the Cell Surface (1939a: 367). Handwritten drafts »are preserved in the Howard collection [of E. E. Just papers at the Howard University Moorland-Spingarn Research Center]: EEJ(H), box 125-21, folder 396« (Manning 1984: 385 note 12). Also, adding recently (25 May 2018) discovered, by Theodore Walker Jr. and Lillie R. Jenkins, typed pages (from box 125-9, folder 162; and from box 125-19, folder 382 [mostly from folder 382 ]) yields 251 pages, now transcribed and edited by T. Walker, L. R. Jenkins, and W. Malcolm Byrnes, in consultation with Stuart Newman, and now called »The Biological Origins and Evolution of Ethical Behavior: From Cells to Humans« $(2019$ [1941]). 
The »origin of man's corporeal being « (»his material being «) is described in terms of evolutionary biology. Similarly, according to Just and Just, the »origin of man's ethical behavior « (»Man as spiritual being ...«) should be described in terms of evolutionary biology. (Just and Just 1941: 6-8).

Darwin, Huxley, Kropotkin, and others had in various ways related ethics to evolutionary influences from sub-human relatives, such as apes and other mammals with brains and central nervous systems and herd instincts. ${ }^{7}$ To this, Just and Just added a more distant reach. They reached further down the biological spectrum, and further back in the history of life on Earth, than contemporary or previous others. They argued that ethical behavior (mutual aid and cooperation with others and with the surrounding environment) »evolved « from our »very most primitive fore-runner« (Just and Just 1941: 12 [also 17]): from cells.

The Just and Just emphasis upon observing »mutual aid« (Kropotkin) and »co-operation « (»ethical behavior«) throughout nature (from the most primitive cells to humans) witnessed against the prevailing overemphasis upon competitive sstruggle for existence, $<$ an overemphasis advanced more by followers of Darwin than by Darwin who was speaking in metaphor (Just and Just 1941: 108, 110, 119 [also p. 240]). This overemphasis produced a crisis for moral theory/ethics conceived as part of natural philosophy. Contrary to generic natural law, this overemphasis made ethical behavior seem unnatural, even contrary to nature. In the postscript »Mutual Aid and Ethics « (1941: 211-243) Just addressed this crisis and its aftermath in the opening paragraph, saying:

The promulgation of the theory of natural selection, emphasizing as it did the struggle for existence, dates a crisis in ethics. Over-emphasized by Darwin's followers, the struggle for existence came soon to be a credo not only in biology but also outside of it. It gave birth to a philosophy that founded a new political school of thought which, in my judgment, came to be more pernicious than the Machiavellian idea which, save for sporadic recrudescenses, was in modern times outmoded. Thus translated, it gave western civilization a new fire, all the more injurious because an invention alleged to be nature's creation. It came to be spiritually a burning of all books about airy dreams wherein Utopias and

7 Evolution and ethics were related in The Descent of Man, and Section in Relation to Sex (1871) by Charles Darwin, in Evolution and Ethics (1894) by Thomas Huxley, in Mutual Aid: A Factor of Evolution (1902) by Peter Kropotkin, and in Ethics: Origin and Development (1924) by Peter Kropotkin. Recent efforts include: Evolution and Ethics: Human Morality in Biological and Religious Perspectives (2004) edited by Philip Clayton and Jeffrey Schloss, and Darwin: A Richer Account of Evolution (2008) edited by John B. Cobb Jr. Also, see »A Sociobiological Expansion of Evolution and Ethics « (1989) by George C. Williams, the preface to the 1989 Princeton edition of Huxley's Evolution and Ethics (1894). 
sequestered isles of peace were chartered. It left only hell burning, made earth a hell of struggle; in the smoke, paradise vanished and with it peace on earth and good will to men.

(Just and Just 1941: 211 [postscript page »a«], italics added)

Similarly, panpsychist-panentheist logician-philosopher Charles Hartshorne had seen that it was important to correct the Darwinian idea that ethical behavior is not natural. In Beyond Humanism: Essays in the Philosophy of Nature (1975 [c1937]) Hartshorne said:

The Darwinian conception of animal life as primarily a ruthless struggle certainly did contaminate ethics extensively. Those who wished to resist this contamination did two things: they emphasized the distinctiveness of man (Huxley), and they pointed out that cooperation is as genuine an aspect of all animal life as conflict, even if the scope of the cooperation is usually very narrow (Kropotkin). This insistence that human love is not an utter stranger in the world was logically $[\leftarrow 29 \mid 30 \rightarrow]$ and psychologically imperative. We must somehow see the world as one, even in respect to ethical problems ...

(Hartshorne 1975 [c1937]: 29-30)

Over-emphasis upon competitive struggle in nature contaminated ethics (Hartshorne 1975 [c1937]: 29) and dated »a crisis in ethics « (Just and Just 1941: 211 [a]). This crisis-inducing over-emphasis was corrected by recognizing the importance of mutual aid and co-operation (ethical behavior) throughout nature, even among cells. Thereby, cell biologist Ernest Everett Just and Hedwig A. Schnetzler Just made an important contribution to moral theory/ ethics.

Now, with the 2018 discovery of this unpublished manuscript, their contribution can be more widely received. In addition to appreciating Just's pioneering contributions to cell biology, now we can better appreciate his contributions to biology-based moral theory. Furthermore, appreciating Just's general biology and bioethics may help with achieving new advances in psychology, anthropology, and social ethics.

\subsection{Psychology, Anthropology, Social Ethics_Traveling a Path Pioneered byJust}

In psychology and anthropology, some theorists are traveling a path converging with biology and ethics, a path pioneered by Just from the 1930 s to 1941. Among preeminent examples, evolutionary influences upon ethical behavior are described by Robert Wright (1994), William F. Allman (1994), Jeremy Rifkin (2009), and Frans de Waal (2009). 
Robert Wright in The Moral Animal: The New Science of Evolutionary Psychology (1994) quotes Charles Darwin predicting that »through study of evolution, >light will be thrown on the origin of man and his history,'« and »>in the distant future the study of psychology >will be based on a new foundation'« (Wright 1994: 3 [Origin of Species, p. $45^{8}$ (Wright endnote 1)]). Wright emphasizes »distant future « by observing that in 1960, 100 years after Origin of Species (1859), historian John C. Greene observed that Darwin would have been disappointed because in 1960 anthropological studies included little study of evolutionary influences [See Darwin and the Modern World View (1961) by John C. Greene]; but, »a revolution started « between 1963 and 1974 when four biologists (William Hamilton; George C. Williams; Robert Trivers; John Maynard Smith) wrote about evolutionary influences upon the social behavior of nonhuman animals (Wright 1994: 4). Then, in 1975, a transdisciplinary synthesis (of social behavior studies in animals and evolutionary biology) produced »sociobiology« in Edward O. Wilson's Sociobiology: The New Synthesis (1975). And since the mid-197os, increasingly, evolutionary biology has been applied to human behavior. This revolutionary paradigm shift is leading to a »new science of evolutionary psychology« (Robert Wright 1994). Similarly, rooting modern psychology and modern behavior in stone age humanity yields evolutionary psychology in William F. Allman's The Stone Age Present: How Evolution Has Shaped Modern Life: From Sex, Violence, and Language to Emotions, Morals, and Communities (1994).

More recently, in Empathic Civilization: The Race to Global Consciousness in a World in Crisis (2009) Jeremy Rifkin offers "a new interpretation of the history of civilization « (p. 1). This new interpretation is based upon a »radical new view of human nature « that is now »emerging in the biological and cognitive sciences « (p. 1). Rifkin says this new interpretation is »forcing us to rethink the long-held belief that human beings are, by nature, aggressive, materialistic, utilitarian, and self-interested « (p. 1). We are being forced to rethink human nature because scientists are now discovering that nature generally is not adequately described by the still prevailing view that evolution is about ssurvival of the fittest $<$ where $>$ the fittest are the most aggressively self-interested. Instead, new research indicates $>$ fitness for survival includes capacity for empathy and cooperative pursuit of mutual wellbeing. Rifkin argues that a realistic hope for overcoming our present global ecological crisis can derive from this new discovery of empathy in nature. Similarly, in The Age of Empathy: Nature's Lessons for a Kinder Society (2009) Frans de Waal argues that new research revealing altruism and fairness among animals can inspire a biology-based pursuit of »a kinder society.« 
And most recently, contemporary researchers are starting to see what E. E. Just reported during the 1930s, cooperative behavior among cells. For instance, see »Team Players: Long thought mostly to compete with one another, microbes turn out to form partnerships that rule the planet «(November 2018) by Jeffrey Marlow and Rogier Braakman.

Natural law is not about »only the Angelicall and human Nature « (Matthew Hale 2015 [1693]: 13). According to cell biologist Ernest Everett Just (1883-1941), from cells to humans, ethical behavior is natural and necessary for evolutionary advances.

In Part II, we will see how astrobiologist/cosmic biologist Sir Fred Hoyle (1915-2001) extends evolutionary biology and life-favoring teleology beyond planet Earth via theories of stellar evolution, cometary panspermia, and cosmic evolution guided by (finely tuned by) providential cosmic intelligence. ${ }^{8}$ And we will see that these theories are consistent with a panentheist »natural theology« that justifies ethical realism. ${ }^{9}$

\section{Biology and Ethics—Beyond Earth Science-Fred Hoyle}

\subsection{Another Scientific Revolution}

Consider the popular idea of two scientific revolutions: a Copernican revolution followed by a Darwinian revolution. This idea is addressed by biologist Francisco J. Ayala in »From Paley to Darwin:Design to Natural Selection«(2008) in Back to Darwin: A Richer Account of Evolution, edited by John B. Cobb Jr. In

8 Biology has been extended beyond planet Earth via theories of stellar evolution, cometary panspermia, and finely tuned cosmic evolution (Hoyle, Wickramasinghe). Psychology has been extended to ultimate extremes (all the way down to observing quantum decisions and nonlocal entanglements, and all the way up to cosmic relations) via quantum physics at the down end and quantum cosmology at the up end. The call for a new »science of consciousness «—advocated in Shadows of the Mind: A Search for the Missing Science of Consciousness (1994) by Roger Penrose-nourished the emergence of quantum cosmology, such as found in a collection of essays in Consciousness and the Universe: Quantum Physics, Evolution, Brain and Mind (2011) edited by Sir Roger Penrose, Stuart Hameroff, and Subhash Kak.

9 Here the term »natural theology« indicates logical study of logos about theos within university research compliant »natural philosophy« or »philosophy of nature«-recently called »science «-and featuring six characteristic commitments distinguished by Erkki Vesa Rope Kojonen: commitment to (1)»realism, « (2) »participatory ontology« such that study of creatures and creations can reveal something about the Creator, (3) a positive view of reason, (4) formulating logical arguments or proofs, (5), valuing rational factual evidence, and (6) the conviction that natural theology has a "positive value for religious life (Kojonen Summer 2017: 4-5 in online preprint). For the sake of moral theory within natural philosophy (natural law/natural ethics), commitment to realism, especially ethical realism, is essential. 
a chapter section—titled »Darwin's Revolution«—Ayala argues persuasively that a »priggish version« of this idea is true, yet inadequate.

I have proposed that this version of the two revolutions is inadequate: what it says is true, but it misses what is most important about these two intellectual revolutions, namely, that they ushered in the beginning of science in the modern sense of the word. These two revolutions may jointly be seen as the one scientific revolution, with two stages, the Copernican and the Darwinian.... Origin of Species is important because it completed the Copernican revolution, initiated three centuries earlier, and thereby radically changed our conception of the universe and the place of mankind in it.

(Ayala 2008: 68)

Ayala holds that Copernicus and Darwin achieved »one scientific revolution with two stages« (2008: 68).

Stage one of this scientific revolution [Copernicus] »consisted in displacing the earth from its previously accepted locus as the center of the universe, moving it to a subordinate place as one more planet revolving around the sun« (Ayala 2008: 67, italics added).

Stage two of this same scientific revolution [Darwin] »consisted in displacing humans from their position as the center of life on Earth, with all other species created for the purpose of humankind, and placing humans instead as one species among many in the living world, so that humans are related to chimpanzees, gorillas, and other species by shared common ancestry« (Ayala 2008: $67-68$, italics added). The Darwinian second stage $» \ldots$ completed the Copernican revolution ... « (Ayala 2008: 68, 69).

Accordingly, scientific revolution stage one (in astronomy) was displacing the Earth from the spatial center of the universe, and placing the Earth in revolution around a star. Then, stage two (in biology) was displacing humans from un-relatedness to other evolving life on Earth. And now, another scientific revolution (in astrobiology and cosmic biology) is displacing the Earth again. Now Earth is no longer conceived to be the biological center of the universe..$^{10}$

10 With regard to displacing humans from the biological center; in Beyond Humanism: Essays in the Philosophy of Nature (1975 [c1937]) Charles Hartshorne says, »the notion that man is the center of the universe « is »not yet completely shattered by astronomy, since we still do not know that we are not the highest of the creatures; but it certainly has no positive support from reason-to say the least, « and Hartshorne conceives of the possibility of creatures »more intelligent or more richly sensitive than we« (1975 [c1937]: 88). Hartshorne also conceived of »intermediate individualities « possibly »interposed between « the universal individual (God) and human individuals (1975 [c1937]: 310). In other words: individuals less inclusive than God, and more inclusive than humans. A similar 
The idea that all life originated in some »warm little pond « (Darwin to Joseph Hooker in 1871) on planet Earth is being replaced with the idea of a vastly larger pond: our Milky Way galaxy (with our solar system embedded in a spiral arm revolving around a galactic center). Moreover, the Milky Way is one among many billions of galactic ponds. Contrary to the astronomically improbable belief that microbial life originated exclusively in our little pond; Fred Hoyle advanced the vastly more probable idea that microbial life as such »did not begin on the Earth « (1980: 21), that »life is not confined to a particular galaxy,« and that »Life can spread itself through the Universe« (1980: 23). Rather than being restricted to Earth, life is »a cosmic phenomenon « (Hoyle and Wickramasinghe 7 August 1986).

\section{$2.2 \quad B^{2} F H$ and Stellar Evolution}

Historically, the revolutionary practice of connecting evolutionary biology to astronomy and cosmology was greatly advanced when Fred Hoyle and others produced evidence indicating the heavy elements (elements heavier than hydrogen and helium, including especially carbon) were synthesized from hydrogen in stars (Hoyle 1946; Hoyle 1947; $B^{2} F H$ 1957). ${ }^{11}$

$B^{2} F H$ is »known to all astronomers « (Martin Rees 1997: 16) as referring to the last name initials of the four authors of »Synthesis of the Elements in Stars« (1957): E. Margaret Burbidge, Geoffrey R. Burbidge, William A. Fowler, and Fred Hoyle. The work signified by $B^{2} F H$ is so widely known because it was »a turning point in our knowledge of how the universe works « (Neil de Grasse Tyson and Donald Goldsmith 2004: 165).

This revolutionary turning point connected biology to stellar evolution. We are made of heavy elements synthesized in previous generations of stars. We are evolved stardust.

Though Fred Hoyle and others did science and mathematics showing that we are stardust; many of us first learned to conceive of ourselves as stardust from musician-poets Crosby, Stills, Nash \& Young singing: »We are stardust. We are golden. We are ten billion year old carbon. And we got to get ourselves back to the garden « (1969 at Woodstock). Since then (Hoyle 1946; Hoyle 1947; $B^{2} F H$ 1957; Woodstock 1969), evolutionary astrobiology (along with advancing

idea was expressed in Fred Hoyle's sci-fi novel The Black Cloud (1957) about an interstellar cloud of organic molecules endowed with a metabolism and intelligence.

11 See »The Synthesis of the Elements from Hydrogen« (1946) and »On the Formation of Heavy Elements in Stars (1947) by Fred Hoyle; and see "Synthesis of the Elements in Stars « (1957) by E. Margaret Burbidge, Geoffrey R. Burbidge, William A. Fowler, and Fred Hoyle / $\mathrm{B}^{2} \mathrm{FH}$. 
theories of »cosmic evolution« and »cosmic biology«) has been displacing the idea that biology is exclusively Earth science. ${ }^{12}$

\subsection{Panspermia, Astrobiology, and Cosmic Biology}

Turning - from Earth-only biology to astrobiology and cosmic biologywas indicated in Fred Hoyle's The Relation of Biology to Astronomy (1980). Here, drawing upon work with Chandra Wickramasinghe, Hoyle argued that interstellar clouds include granular particles of bacteria. Hoyle and Wickramasinghe advanced a theory of water, organic materials, and microbial life being circulated by comets called »cometary panspermia« (1981a; 1982; 1983; 1 December 1984). And they advanced $\gg$ the Case for Life as a Cosmic Phenomenon « (7 August 1986 [also Wickramasinghe and Tokoro January 2014; Wickramasinghe, K. Wickramasinghe, and Tokoro 2019]).

Hoyle predicted that the idea of interstellar and cosmic microbiological processes will become obvious to future generations. Hoyle said:

I suspect that the cosmic quality of microbiology will seem as obvious to future generations as the Sun being the centre of our solar system seems obvious to the present generation.

(Hoyle 1980: 24-25)

Hoyle's 1980 prediction is coming true. The cosmic quality of microbiology is becoming more and more obvious. And the once »maverick science of astrobiology (Darling 2001) is now becoming less and less maverick. ${ }^{13}$

12 Concerning »cosmic evolution« and »cosmic biology, «see: Origins: Fourteen Billion Years of Cosmic Evolution (2004) by Neil de Grasse Tyson and Donald Goldsmith; »Imperatives of Cosmic Biology« (2 March 2010) by Chandra Wickramasinghe and Carl H. Gibson; Cosmic Biology: How Life Could Evolve on Other Worlds (c2011) by Louis N. Irwin and Dirk Schulze-Makuch; and Vindication of Cosmic Biology: Tribute to Sir Fred Hoyle (1915-20or) (2015) edited by Chandra Wickramasinghe. Concerning relations between astronomy and biology: In 1937 in Beyond Humanism: Essays in the Philosophy of Nature (1975 [c1937]) Charles Hartshorne was saying »astronomy is not as yet of much help in determining the prevalence in space-time of conditions favoring animal organism « (58). Since then, especially since $B^{2} F H$ (1957), astronomers have learned to be of much help to biology; and in so doing, they created the new convergent disciplines of astrobiology and cosmic biology.

13 In Life Everywhere: The Maverick Science of Astrobiology (2001) David Darling says, with regard to panspermia theories advanced by Hoyle and Wickramasinghe, »Today ... panspermia is at least tolerated « and »the idea of microbes being able to hop from world to world has very much entered the scientific mainstream « (47). Also, see The Living Universe: NASA and the Development of Astrobiology (2005 [c2004]) by Steven J. Dick (chief NASA historian) and James E. Strick. Also see: (Hoyle and Wickramasinghe 30 March 1979), (Hoyle and Wickramasinghe 6 November 1979), and (Hoyle and Wickramasinghe 1981; 1982; September 1983; December 1983; 1984). 
The previous scientific revolution (in astronomy and biology) displaced Earth from the spatial center of the universe (Copernicus 1543) and displaced humans from un-relatedness to other evolving life on Earth (Darwin 1859). The current scientific revolution (in astrobiology and cosmic biology) is displacing Earth from the biological center of the universe, and theory of evolution on Earth is displaced from un-relatedness to stellar, galactic, and cosmic evolution ( $\mathrm{B}^{2} \mathrm{FH}$ 1957). Furthermore, this Copernicus-like revolution is producing a cosmic biology (Hoyle and Wickramasinghe 1979; 1980; 1981a; 1982; 8 September 1983; 1 December 1983; 1984; 7 August 1986) that is consistent with natural theology (Hoyle 1984 [c1983]; Hoyle and Wickramasinghe 1981b; 1988).

\subsection{Consistent with Natural Theology}

Hoyle and Wickramasinghe argue that precisely tuned life-favoring cosmic circumstances are required to make life possible. The »coupling constants « of physics must be chosen with enormous precision (Hoyle and Wickramasinghe 1981b: 141-43; also Hoyle 1984 [c1983]: 218-19). Creating and sustaining such enormously precise cosmic circumstances (today called »cosmic fine tuning «) requires deliberate acts of a »super intelligence, « an interacting and »allembracing intelligence « (Hoyle 1984 [c1983]: 215). The numerical calculations put the need for cosmic intelligence-exercising cosmic influences—beyond question.

A commonsense interpretation of the facts suggests that a superintellect has monkeyed with physics, as well as with chemistry and biology, and that there are no blind forces worth speaking about in nature. The numbers one calculates from the facts seem to me to be so overwhelming as to put this conclusion beyond question.

(Hoyle 1981b:12)

Furthermore, given the extreme complexity of even the smallest living microbe, mathematical calculations witness against the still prevailing theory of life emerging from non-life by random/chance assembly.

The chance that life forms might have emerged in this way [by way of random assembly, T.W.] is comparable with the chance that a tornado sweeping through a junk-yard might assemble a Boeing 747 from material therein.

(Hoyle 1981a: 105)

A commonsense interpretation of the facts forced Hoyle to conclude (against his previous atheism) that a cosmic intelligence must be exerting cosmic influences favoring the evolution of life. This implicitly pro-theological 
conclusion is rendered explicit in chapter 9 »Convergence to God « in Evolution from Space: A Theory of Cosmic Creationism (1981b) by Fred Hoyle and N. Chandra Wickramasinghe. ${ }^{14}$

This revolutionary practice- of connecting evolutionary biology to creationist cosmology and natural theology - was anticipated and advanced by natural philosophers thinking deeply about science and biology. For instance, in Science and the Modern World (1925) Alfred North Whitehead conceived that science was becoming »the study of organisms « (103), with physicists studying the smaller organisms, and biologists studying the larger organisms. And, with emphasis upon universal creativity, Whitehead connected his biology-oriented "philosophy of organism « to cosmology and theology in Process and Reality: An Essay in Cosmology (1927-28). Similarly, biology was connected to ontology, evolutionary cosmology, and natural theology in Beyond Humanism: Essays in the Philosophy of Nature (1975 [c1937]) by Charles Hartshorne. Here Hartshorne held that »the structure of reality« is »one of organisms within organisms « (91), that »the philosophical argument for cosmic evolutionism stands on its own feet« (140; italics added), and we are »cells in the body of God« (197).

Revolutionary advances in astrobiology and cosmic biology are catching up to philosophical anticipations, and connecting agreeably with »a quiet revolution « in theology identified in M. W. Brierley's »Naming a Quiet Revolution: The Panentheistic Turn in Modern Theology « (2004). At »the panentheistic turn, « theology converges with cosmic biology, ${ }^{15}$ and with ethics.

14 Concerning God, biology, evolution, creation, and cosmic creationism: See »Hoyle on Evolution « (12 November 1981) by Fred Hoyle in Nature; chapter 1-»Chance and the Universe «-in The Intelligent Universe: A New View of Creation and Evolution (1984 [c1983]) by Fred Hoyle; and chapter 10-»The Concept of a Creator «-in Cosmic Life-Force (1990) by Fred Hoyle and N. Chandra Wickramasinghe. And, from among theologians at the Perkins School of Theology, see Sisters of Dust, Sisters of Spirit: Womanist Wordings on God and Creation (1998) by Karen Baker-Fletcher, and The Big Bang and God: An Astro-Theology ... (2015) by Theodore Walker Jr. and Chandra Wickramasinghe [where »Astro-Theology « indicates a constructive postmodern revision of early modern Astro-Theology: Or, A Demonstration of the Being and Attributes of God, from a Survey of the Heavens (1715) by William Derham]; and note that in a chapter titled »It's Only Natural« Craig C. Hill [a New Testament scholar attentive to biology] says, »... perhaps our biology is meant to drive us to God « (Hill 2016: 21).

15 Concerning panentheism and evolution, see: A Natural Theology for Our Time (1967) by Charles Hartshorne; Analytic Theism, Hartshorne, and the Concept of God (1996) and Whitehead's Religious Thought: From Mechanism to Organism, from Force to Persuasion (January 2017) by Daniel A. Dombrowski; »Panentheism: A Field-Oriented Approach « (2004) and »Actual Entities and Societies, Gene Mutations and Cell Development: Implications for a New World View« (Spring/Sumer 2013) by Joseph Bracken; »Evolution 


\subsection{Panentheism and Ethical Realism}

Panentheism helps with discerning that the biblical imperatives-to love our neighbors and our enemies as we love ourselves (Matthew 5:43-48; 22:34-40) are imperatives founded upon realism, not mere idealism. Every experience confirms (by exemplifying) what no experience can deny: we really are partly inclusive parts among variously inclusive parts of reality. And logical/mereological analysis shows that all parts of reality are parts of the whole of reality, parts of »the one all-inclusive [divine, T.W.] whole of realty « (Ogden 1984: 21; also Hartshorne 1973 [1967]). Hence, conformity to reality (living righteously, not missing the mark [not sinning]) requires valuing neighbors, enemies, and selves as they/we really are: as parts among parts of the divine whole. This ethical realism is justified by panentheism.

\section{References}

Allman, W.F. (1994) The Stone Age Present: How Evolution Has Shaped Modern LifeFrom Sex, Violence, and Language to Emotions, Morals, and Communities. New York: Simon \& Schuster.

Ayala, F.J. (2008) »From Paley to Darwin: Design to Natural Selection.« In: Cobb, J.B. (ed.) Back to Darwin: A Richer Account of Evolution. Grand Rapids, Michigan: William B. Eerdmans, 50-75.

Baker-Fletcher, K. (1998) Sisters of Dust, Sisters of Spirit: Womanist Wordings on God and Creation. Minneapolis: Fortress Press.

Barbour, I.G. (2008) »Evolution and Process Thought.« In: Cobb, J.B. Jr. (ed.) Back to Darwin: A Richer Account of Evolution. Grand Rapids: Eerdmans, 196-214.

Bracken, J. (2004) »Panentheism: A Field-Oriented Approach.« In: Clayton, P. and Peacocke, A. (eds.) In Whom We Live and Move and Have Our Being: Panentheistic Reflections on God's Presence in a Scientific World. Grand Rapids: Eerdmans.

Bracken, J.A. (Spring/Summer 2013) »Actual Entities and Societies, Gene Mutations and Cell Development: Implications for a New World View.« Process Studies, 42(1), 64-76.

Brierley, M.W. (2004) »Naming a Quiet Revolution: The Panentheistic Turn in Modern Theology.« In: Clayton, P. and Peacocke, A. (eds.) Whom We Live and Move and Have

and Process Thought« (2008) by Ian G. Barbour; »Organisms as Agents in Evolution« (2008) by John B. Cobb Jr.; "Whitehead's Naturalism and a Non-Darwinian View of Evolution« (2008) by David Ray Griffin; »A Process Cosmology« (September 2012) by Lewis S. Ford; »polyamorous panentheism« $(77-81 ; 207)$ in Intercarnations: Exercises in Theological Possibility (2017) by Catherine Keller; and Entangled Worlds: Religion, Science, and New Materialisms (2017) edited by Catherine Keller and Mary-Jane Rubenstein. 
Our Being: Panentheistic Reflections on God's Presence in a Scientific World. Grand Rapids: Eerdmans.

Brüntrup, G. and Jaskolla, L. (eds.) (2017 [2016]) Panpsychism: Contemporary Perspectives. New York: Oxford University Press.

Burbidge, E.M. with Burbidge G.R., Fowler W.A., and Hoyle, F. [B²FH]. (October 1957) »Synthesis of the Elements in Stars. « Review of Modern Physics, 29(4), 547-650 [doi:10.1103/RevModPhys.29.547].

Byrnes, W.M. (2009) »Ernest Everett Just, Johannes Holtfreter, and the Origin of Certain Concepts in Embryo Morphogenesis.« Molecular Reproduction \& Development, 76 , 912-921.

Byrnes, W.M. (February 2010) »Ernest Everett Just: Experimental Biologist Par Excellence.«Via the American Society for Biochemistry and Molecular Biology, online at $<$ www.asbmb.org/asbmbtoday/asbmbtoday_article.aspx?id=5878>.

Byrnes, W.M. and Eckberg, W.R. (1 August 2006) »Ernest Everett Just (1883-1941) —An early ecological developmental biologist.« Developmental Biology, 296(1), 1-11, online at <http://dx.doi.org/10.1016/j.ydbio.2006.04.445>.

Clayton, P. and Schloss, J. (eds.) (2004) Evolution and Ethics: Human Morality in Biological and Religious Perspectives. Grand Rapids: Eerdmans.

Clayton, P. and Peacocke A. (eds.) (2004) In Whom We Live and Move and Have Our Being: Panentheistic Reflections on God's Presence in a Scientific World. Grand Rapids: Eerdmans.

Cobb., J.B. Jr. (2008) »Organisms as Agents in Evolution« is Chapter 14 (215-242) in: Cobb, J.B. Jr. (ed.) Back to Darwin: A Richer Account of Evolution. Grand Rapids: Eerdmans.

Cooper, J.W. (2006) Panentheism-The Other God of the Philosophers: From Plato to the Present. Grand Rapids, Michigan: Baker Academic Publishing Group.

Copernicus, N. (1543) De revolutionibus orbium coelestium, libri VI. Budapest: Tancsics Konyvkiado, 1973 .

Crow, J.F. (August 2008) »Just and Unjust: E.E. Just (1883-1941).« Genetics, 179, 1735-1740. Darling, D. (2001) Life Everywhere: The Maverick Science of Astrobiology. New York: Basic. Darwin, Ch. (1859) On the Origin of Species By Means of Natural Selection, Or the Preservation of Favoured Races in the Struggle for Life. London: John Murray.

Darwin, Ch. (1871) The Descent of Man, and Selection in Relation to Sex. London: John Murray.

de Waal, F.B.M. (2006) Primates and Philosophers: How Morality Evolved. Princeton, NJ: Princeton University Press.

de Waal, F.B.M. (2009) The Age of Empathy: Nature's Lessons for a Kinder Society. New York: Harmony Books.

de Waal, F.B.M. (2019) Mama's Last Hug: Animal Emotions and What They Tell Us about Ourselves. New York: W. W. Norton. 
de Waal, F.B.M. and Patricia S.C. with T. Pievani and S. Parmigiani (eds.) (2014) Evolved Morality: The Biology and Philosophy of Human Conscience. Leiden; Boston: Brill.

Derham, W. (1715) Astro-Theology: Or, A Demonstration of the Being and Attributes of God, from a Survey of the Heavens. London: William Innys.

Dick, S.J. [chief NASA historian] and J. E. Strick (2005 [c2004]). The Living Universe: NASA and the Development of Astrobiology. Rutgers University Press.

Dombrowski, D.A. (1996) Analytic Theism, Hartshorne, and the Concept of God. Albany, New York: State University of New York Press.

Dombrowski, D.A. (January 2017) Whitehead's Religious Thought: From Mechanism to Organism, from Force to Persuasion. Albany: State University of New York Press.

Dover, C. (June 1954) »The Significance of the Cell Surface (The Work of E.E. Just).« Journal of the Zoological Society of India, 6 (1), 3-42.

Ford, L.S. (September 2012) »A Process Cosmology.« Journal of Cosmology 20, 86458647 , online at $<$ journalofcosmology.com $>$.

Gamwell, F.I. (1984). Beyond Preference: Liberal Theories of Independent Associations. Chicago: University of Chicago Press.

Gamwell, F.I. (1996 [1990]). The Divine Good: Modern Moral Theory and the Necessity of God. Foreword by David Tracy. Dallas, Texas: Southern Methodist University Press.

Göcke, B.P. (2018) The Panentheism of Karl Christian Friedrich Krause (1781-1832): From Transcendental Philosophy to Metaphysics. New York: Peter Lang.

Graff, H.J. (2015) Undisciplining Knowledge: Interdisciplinarity in the Twentieth Century. Baltimore: John Hopkins University Press.

Greene, J.C. (1961) Darwin and the Modern World View. Baton Rouge: Louisiana State University Press; New York: American Library, 1963.

Griffin, D.R. (2007) Whitehead's Radically Different Postmodern Philosophy:An Argument for its Contemporary Relevance. Albany: State University of New York Press.

Griffin, D.R. (2008) »Whitehead's Naturalism and a Non-Darwinian View of Evolution.« Chapter 22 (364-39o) in: Back to Darwin: A Richer Account of Evolution, edited by John B. Cobb Jr. Grand Rapids: Eerdmans.

Griffin, D.R. (2014) Panentheism and Scientific Naturalism: Rethinking Evil, Morality, Religious Experience, Religious Pluralism, and the Academic Study of Religion. Claremont, California: Process Century Press.

Grinnell, F. (August 1975) »Cell attachment to a substratum and cell surface proteases.« Archives of Biochemistry and Biophysics, 169(2), 474-482, online at https://doi. org/10.1016/0003-9861(75)90190-3.

Hale, M. (2015 [originally 1693]) Of the Law of Nature, edited by David S. Sytsma. Grand Rapids, Michigan: CLP Academic.

Hamilton, W.D. (1963)»The Evolution of Altruistic Behavior.« American Naturalist, 97, 354-56 (Wright 1994: 434). 
Harman, O. (2013) »A History of the Altruism-Morality Debate in Biology.« (11-29) In: Evolved Morality: The Biology and Philosophy of Human Conscience, edited by F.B.M. de Waal, P.S. Churchland, T. Pievani, and S. Parmigiani. Leiden; Boston: Brill, 2014.

Hartshorne, Ch. (c1937) Beyond Humanism: Essays in the Philosophy of Nature. Gloucester, Mass.: P. Smith, reprint with new preface 1975.

Hartshorne, Ch. (1967) A Natural Theology for Our Time. La Salle, Illinois: Open Court Publishing, reprint 1973 .

Hartshorne, Ch. (1970). Creative Synthesis and Philosophic Method. La Salle, Illinois: Open Court.

Hartshorne, Ch. (1984) Chapter 2 »The Physical and the Spiritual« and Chapter 3 »Creation Through Evolution.«In: Omnipotence and Other Theological Mistakes. Albany, New York: State University of New York Press.

Hartshorne, Ch. (1997) The Zero Fallacy and Other Essays in Neoclassical Philosophy, edited by Mohammad Valady. La Salle: Open Court.

Hartshorne, Ch. and W.L. Reese. (1953) Philosophers Speak of God. Chicago: University of Chicago Press; Midway, 1976; Humanity, 2000.

Hill, C.C. (2016) »It's Only Natural.« Chapter 2 in Servant of All: Status, Ambition, and the Way of Jesus. Grand Rapids: Eerdmans.

Hoyle, F. (2 December 1946 [April 6]) »The Synthesis of the Elements from Hydrogen.« Monthly Notices of the Royal Astronomical Society, 106(5), 343-83.

Hoyle, F. (1947) »On the Formation of Heavy Elements in Stars.« Proceedings of the Physical Society 59(6), 972-78.

Hoyle, F. (1980) The Relation of Biology to Astronomy. Cardiff, Wales: University College Cardiff Press, a 15 April 1980 preprint booklet.

Hoyle, F. (12 November 1981a) »Hoyle on Evolution.« Nature, 294(5837), 104-05 [doi:10.1038/294104bo]. Here is Hoyle's famous »chance that a tornado sweeping through a junk-yard might assemble a Boeing 747 « analogy for evolution by chance assembly.

Hoyle, F. (November 1981b) »The Universe: Past and Present Reflections. «ngineering and Science, 8-12.

Hoyle, F. (1984 [c1983]). The Intelligent Universe: A New View of Creation and Evolution. New York: Holt, Rinehart and Winston.

Hoyle, F. and N.C. Wickramasinghe (1979 [30 March 1979]) »On the Nature of Interstellar Grains.« Astrophysics and Space Science, 66(1), pp. 77-90.

Hoyle, F. and N.C. Wickramasinghe (May 1980 [6 November 1979]) »Organic Grains in Space.« Astrophysics and Space Science, 69(2), 511-13.

Hoyle, F. and N.C. Wickramasinghe (1981a [1980]) »Comets-a Vehicle for Panspermia.« Comets and the Origin of Life: Proceedings of the Fifth College Park 
Colloquium on Chemical Evolution, October 29-31, University of Maryland, edited by Cyril Ponnamperuma. Boston: Kluwer.

Hoyle, F. and N.C. Wickramasinghe (1981b) »Convergence to God« is chapter 9 in: Evolution from Space: A Theory of Cosmic Creationism. New York: Simon and Schuster, 129-45.

Hoyle, F. and N.C. Wickramasinghe. (1982) »Comets.« Section C (23-35) in: Proofs that Life is Cosmic: Memoirs of the Institute of Fundamental Studies. Sri Lanka: Government Press.

Hoyle, F. and N.C. Wickramasinghe (8 September 1983)»Organic Grains in Taurus Interstellar Clouds. «Nature, vol. 305, issue 5930, 161 [doi:10.1038/305261ao].

Hoyle, F. and N.C. Wickramasinghe (1 December 1983) »Bacterial Life in Space.« Nature, vol. 306, issue 5942, 420 [doi:10.1038/306420ao].

Hoyle, F. and N.C. Wickramasinghe. (1984) From Grains to Bacteria. Cardiff: University College Cardiff Press.

Hoyle, F. and N.C. Wickramasinghe. (7 August 1986) »The Case for Life as a Cosmic Phenomenon.« Nature, 32(6079), 509-11 [doi:10.1038/322509ao].

Hoyle, F. and N.C. Wickramasinghe (1988) »The Concept of a Creator« is chapter 10 in: Cosmic Life-Force. London: J. M. Dent; New York: Paragon, 1990, 132-44.

Huxley, Th. (1894) Evolution and Ethics. Princeton University Press, 1989.

Jahr, F. (1927) »Bio-Ethics: A Review of the Ethical Relationships of Humans to Animals and Plants. « Kosmos 24(4) [as cited by Sass (2007)].

Just, E.E. (1933)»Cortical Cytoplasm and Evolution.« American Naturalist, 67(708), 20-29.

Just, E.E. (1939a) The Biology of the Cell Surface. Philadelphia: P. Blakiston's Son [New York: Garland Publishing, 1988 reprint].

Just, E.E. (1939b) Basic Methods for Experiments onEggs of Marine Animals. Philadelphia: P. Blakiston's Son.

Just, E.E. (April 1940) »Unsolved Problems of General Biology.«Physiological Zoology, $13(2), 123-42$.

Just, E.E. and H.A. Schnetzler Just (October 1941) »The Origin of Man's Ethical Behavior.« Unpublished (as of March 2020).

Keller, C. (2017) Intercarnations: Exercises in Theological Possibility. New York: Fordham University Press.

Keller, C. and M.-J. Rubenstein, (eds.) (2017) Entangled Worlds: Religion, Science, and New Materialisms. New York: Fordham University Press.

Kojonen, E.V.R. (Summer 2017) »Natural Theology in Evolution: A Review of Critiques and Changes. « European Journal for Philosophy of Religion, 9(2), 83-117.

Kropotkin, P.A. (1902) Mutual Aid: A Factor of Evolution, edited by Charles Aldarondo. Kindle Edition: Amazon Digital Services, based upon print edition ISBN 1502589664; CreateSpace Independent Publishing Platform, 2014. 
Kropotkin, P.A. (1924) Ethics: Origin and Development, edited by N. Lebedev, translated from the Russian by Louis S. Friedland and Joseph R. Piroshnikoff. New York: Dial Press.

Leopold, A. (1949) A Sand County Almanac, and Sketches Here and There, illustrated by Ch. W. Schwartz. New York: Oxford University Press.

Lillie, F.R. and E.E. Just (1924) »Fertilization. «A chapter in: General Cytology: A Textbook of Cellular Structure and Function for Students of Biology and Medicine, edited by E.V. Cowdry. Chicago: University of Chicago.

Manning, Kenneth R. 1984 [c1983]. Black Apollo of Science: The Life of Ernest EverettJust. Oxford: Oxford University Press.

Marlow, J. and R. Braakman (November 2018) »Team Players: Long thought mostly to compete with one another, microbes turn out to form partnerships that rule the planet.« Scientific American, 319 (5), 32-39.

Niebuhr, R. (1932) Moral Man and Immoral Society: A Study in Ethics and Politics. New York: Charles Scribner's Sons.

Ogden, S.M. (1966) The Reality of God and Other Essays. New York: Harper \& Row.

Ogden, S.M. (Spring 1984). »Process Theology and the Wesleyan Witness.« Perkins School of Theology Journal, vol. 37, issue 3, 18-33 [reprinted in Thy Nature and Thy Name Is Love: Wesleyan and Process Theologies in Dialogue (2001), edited by Bryan P. Stone and Thomas Jay Oord].

Penrose, R. (1994) Shadows of the Mind: A Search for the Missing Science of Consciousness. Oxford: Oxford University Press.

Penrose, R., with S. Hameroff and S. Kak, (eds.) (2011) Consciousness and the Universe: Quantum Physics, Evolution, Brain and Mind. Cambridge, MA: Cosmology Science Publisher, a collection of essays from the Journal of Cosmology, vol. 3, December 2009; and vol. 14, April-June 2011.

Potter, V.R. (1971). Bioethics: Bridge to the Future, edited by C.P. Swanson. Englewood Cliffs, New Jersey: Prentice-Hall.

Potter, V.R. (1988) Global Bioethics: Building on the Leopold Legacy, foreword by H. Tristram Englehardt Jr. East Lansing, Michigan: Michigan State University Press.

Rees, M. (1997) Before the Beginning: Our Universe and Others, foreword by Stephen Hawking. Cambridge: Helix Books.

Renwick, C. (2016) »Biology, social science, and history: interdisciplinarity in three directions. «In: Palgrave Communications, 2(16001) doi:10.1057/palcomms.2016.1.

Rifkin, J. (2009) Empathic Civilization: The Race to Global Consciousness in a World in Crisis. New York: Penguin.

Sass, H. (December 2007). »Fritz Jahr's 1927 Concept of Bioethics. « Kennedy Institute of Ethics Journal, 17(4), 279-295.

Stone, B.P. and T.J. Oord (eds.) (2001) Thy Nature and Thy Name Is Love: Wesleyan and Process Theologies in Dialogue. Nashville: Abingdon. 
Trivers, R. (1971) »The Evolution of Reciprocal Altruism.« Quarterly Review of Biology, (46), 35-56. (Wright 1994: 443)

Trivers, R. (1985) Social Evolution. Menlo Park, Cal.: Benjamin/Cummings. (Wright 1994: 444)

Tyson, N.d.G. and D. Goldsmith (2004) Origins: Fourteen Billion Years of Cosmic Evolution. New York: Norton.

Uexküll, J.v. (1926) Theoretische Biologie, Zweite Gänzlich Neu Bearbeitete Auflage [Theoretical Biology, second completely new edited edition]. Berlin:Springer-Verlag, 1928.

[Jakob Jonann Baron von Uexküll, born 1864, died 1944]

Uexküll,J.v. and G. Kriszat (1934)Streifzüge durch die Umweltenvon Tieren und Menschen. Ein Bilderbuch unsichtbarer Welten (Verständliche Wissenschaft-Einundzwanzigster Band). Berlin: Julius Springer [Springer-Verlag]. [A Foray into the Worlds of Animals and Humans: With a Theory of Meaning, translated by J.D. O'Neil. University of Minnesota Press, 2010.]

Walker, T. Jr. and C. Wickramasinghe [editing by Alexander Vishio]. 2015. The Big Bang and God: An Astro-Theology wherein an astronomer and a theologian offer a study of interdisciplinary convergences with natural theology both in the scientific researches of Sir Fred Hoyle and in the philosophical researches of Charles Hartshorne and Alfred North Whitehead, thereby illustrating a constructive postmodern trend. New York: Palgrave Macmillan.

Whitehead, A.N. (1925) Science and the Modern World (Lowell Lectures, 1925). New York: Macmillan; Free Press, 1967.

Whitehead, A.N. (1927-28) Process and Reality: An Essay in Cosmology (Gifford Lectures), Corrected Edition, edited by D.R. Griffin and D.W. Sherburne. New York: Free Press, 1978.

Whitehead, A.N. (1933) Adventures of Ideas. New York: Macmillan.

Whitehead, A.N. (c1934) Nature and Life. Chicago: University of Chicago Press.

Whitehead, A.N. (19479 Essays in Science and Philosophy. New York: Philosophical Library.

Wickramasinghe, C. (ed.) (2015) Vindication of Cosmic Biology: Tribute to Sir Fred Hoyle (1915-2001). Hackensack, NJ: World Scientific.

Wickramasinghe, C. and C.H. Gibson. (2 March 2010 [27 February]) »Imperatives of Cosmic Biology.« In: Inspire: High Energy Physics Information System, subject: Cosmology and Nongalactic Astrophysics (astro-ph.CO); Astrophysics of Galaxies (astro-ph.GA), 17 pages [arXiv:1003.0091].

Wickramasinghe, Ch. and G. Tokoro. (January 2014) »Life as a Cosmic Phenomenon: 2. The Panspermia Trajectory of Homo sapiens. «In: Astrobiology and Outreach, vol. 2, issue 2, 115 [doi:10.4172/2332-2519.1000115]. 
Wickramasinghe, C., with K. Wickramasinghe and G. Tokoro (2019) Our Cosmic Ancestry in the Stars: The Panspermia Revolution and the Origins of Humanity. Simon \& Schuster Digital Sales.

Williams, G.C. (1966) Adaptation and Natural Selection: A Critique of Some Current Evolutionary Thought. Princeton: Princeton University Press.

Williams, G.C. (1989) »A Sociobiological Expansion of Evolution and Ethics.«preface to Evolution and Ethics (Princeton University Press, 1989 [1894]) by Th. Huxley.

Williams, K.M. with B.A. Wilson, W.G. O'Connor, and M.S. Willis (2013) »Ernest Everett Just, PhD: Pioneer in Ecological Developmental (Eco-Devo) Biology.«Journal of the South Carolina Academy of Science, 11(1), article 5.

Wilson, E.O. (1975) Sociobiology: The New Synthesis. Harvard University Press.

Wright, R. (1994) The Moral Animal: The New Science of Evolutionary Psychology. New York: Pantheon Books. 